\section{Japanese plans delayed despite Clinch River bonus}

Tokyo

JAPAN'S fast breeder reactor (FBR) research programme is running into financial difficulties, despite the recent gift of Y200-million-worth of unwanted research equipment and instruments from the US Government's abandoned Clinch River project.

The difficulties are caused by a massive increase in estimates of the construction costs for Monju, a 300-MW sodium-cooled prototype FBR to be constructed near Tsuruga in Fukui Prefecture. Monju is the key project in the FBR development programme and a major step forward from the 100-MW experimental reactor Joyu, which went critical in 1977.

Ground clearance operations have begun at the Monju site after several years of geological and seismic surveys. But construction costs have now risen from the 1980 estimate of Y 400,000 million (US\$1,600 million) to around Y590,000 million ( $\$ 2,500$ million). Responsibility for the project rests with the Power Reactor and Nuclear Fuel Development Corporation, a large research organization attached to the Science and Technology Agency. Funds for the project are not, however, entirely provided by the government, around 20 per cent coming, under a 1980 agreement, from privately-owned electricity utilities, largely through a power source development tax.

Now, the Science and Technology Agency wants to pass on a third of the extra costs to the utilities. They, however, have refused point blank to increase their contribution, arguing that any further funds could be found only by increasing electricity charges - something the government is anxious to avoid.

The shortage of funds is likely to hit the project hard next year when construction should move into top gear so as to finish by 1990. At present, given that the Japanese Government is already running an enormous budget deficit, the most likely option is to postpone the completion date by up to 5 years and to slow down the rate of construction to match availability of funds.

The pessimism over completing Monju on time comes just as the federation of electric power companies and the big five nuclear construction companies have launched a new Y6,000 million ( $\$ 25$ million) study project to choose the basic design for Monju's successor, a 1,000-MW demonstration reactor expected to be ready by the end of the century. The three-year study will aim to make the choice between a loop type design, in which heat from the primary sodium coolant is transferred to a secondary liquid sodium system outside the reac- tor, and a tank type in which the heat exchanger is located inside the reactor. The two reactor types are being researched by groups led by Mitsubishi and HitachiToshiba respectively.

The key to success is to find some way to cut the enormous construction costs of the FBR, currently estimated at around two and a half times that of a conventional light water reactor. One way in which this will be

\section{Copenhagen}

THE Niels Bohr Institute for nuclear and particle physics in Copenhagen, which celebrates the centenary of Bohr's birth next year, is in dire straits because of opposition to nuclear power in Denmark. That, at least is the opinion of one of its professors, nuclear theorist Aage Winther. For the result is poor student enrolment in physics at the University of Copenhagen (of which the Niels Bohr Institute is a part), and some departments with five physics lecturers per student. Because university research funds are distributed in rough proportion to student numbers, these are hard times for the Bohr Institute.

There have been no new research posts at the institute for seven years. With a staff of 50 , the institute needs one or two posts a year to keep alive, Winther reckons. A clutch of retirements begins in five years' time, but meanwhile, the institute needs perhaps $10-15$ new staff. Will it happen? Winther throws up his hands in a gesture of doubt. Sad news for a city that gave its name to the statistical interprepation of quantum mechanics and for the institute that housed Europe's first cyclotron. The Niels Bohr also began the European Organization for Nuclear Research (CERN), now based near Geneva, as a theoretical group in 1951.

The trouble lies not only with the opposition of the young to things nuclear and the fashion (as Winther describes it) for the new biology. The Danish university system, in which the Niels Bohr is enmeshed, is in something of a mess. First degrees typically take 8-10 years to complete, with some students stretching out their time to the age of 34. After such a long first degree, there are very few postgraduate students.

Also, as in many countries, research of counting pencils and erasers"'. The goverment expected the universities to perform major surgery on themselves, says Winther. "But how can we do that with our funds have been pared down "to the level tackled is through a joint US-Japanese project, agreed in principle this week, to perfect methods of driving the sodium coolant by electromagnetic forces rather than by a conventional pump.

Technical specifications for the reactor are to be examined by the French company Novatome, for although enthusiasm for FBRs remains great in Japan, the technology is still a long way behind that of France. The French began operation of a 250-MW prototype FBR, the Phénix, in 1972 (at the same time as a similar reactor at Dounreay in the United Kingdom) and expect to have Super-Phénix - the world's first demonstration FBR - ready by 1985 , some 15 years ahead of any Japanese competitor.

Alun Anderson

\title{
Niels Bohr on a shoestring
}

democratic structures?' All university committees have 25 per cent representation from students and 25 per cent from technicians, says Professor Teder Olesen Larsen, chairman of the national science policy advisory committee. "With such a broad structure the only decisions the universities can take are decisions to do nothing."

Thus the Niels Bohr Institute and many other important laboratories in Denmark's universities, have been submerged except where they can fight for special support. This is often distributed by the government in "cigar boxes", a Danish phrase for special-purpose funds administered separately from the 10 per cent or so of research money that comes through the Danish research council system. Thus when essential moneys were allocated for the re-instrumentation of Danish laboratories, the money came from a "cigar box", where research council priorities were not easy to take into account. With so many special funds, the Danish research support system has now become "Kafkaesque", says Olesen Larsen.

The Niels Bohr is hoping to insulate itself from these problems in two ways. First it has negotiated a deal with the government that will give it more funds than its low student intake would normally entail. But the money will go in a lump to the university administration, and it is yet to be seen whether it comes the institute's way, says a cynical Winther. But as a second string, the Niels Bohr is hoping to raise more external support - which, with 50 mostly foreign visiting scientists, is already large. "We hope to make a success of our 100th anniversary celebration next year"', says Winther, "by appealing to our external benefactors". Among them have been the US Ford Foundation and National Science Foundation; the Nishima Foundation of Japan; and the Italian national institute for nuclear physics (INFN). They should expect a few discreet Danish knocks on their doors next year. Robert Walgate 